Article

\title{
The Use of Waste Biomass from the Wood Industry and Municipal Sources for Energy Production
}

\author{
Andrzej Greinert ${ }^{1, * \mathbb{D}}$, Maria Mrówczyńska ${ }^{2}$ and Wojciech Szefner ${ }^{3}$ \\ 1 Institute of Environmental Engineering, University of Zielona Góra, 65-516 Zielona Góra, Poland \\ 2 Institute of Civil Engineering, University of Zielona Góra, 65-516 Zielona Góra, Poland; \\ M.Mrowczynska@ib.uz.zgora.pl \\ 3 Lubuski Centre for Innovation and Agricultural Implementation Ltd., University of Zielona Gora, Co., \\ Kalsk 122, 66-100 Sulechów, Poland; w.szefner@loiiwa.com.pl \\ * Correspondence: A.Greinert@iis.uz.zgora.pl
}

Received: 9 May 2019; Accepted: 29 May 2019; Published: 31 May 2019

check for updates

\begin{abstract}
Biomass can be used for the production of energy from renewable sources. Because of social resistance to burning crop plants, mixtures and pellets made from or including waste materials are a good alternative. The mixtures analyzed, prepared from wood and municipal waste, were characterized for their calorific values, $7.4-18.2 \mathrm{MJ} \cdot \mathrm{kg}^{-1}$. A result, over $15 \mathrm{MJ} \cdot \mathrm{kg}^{-1}$ was obtained for $47 \%$ of the quantities of mixtures being composed. It has been demonstrated that wood shavings and sewage sludge have a stabilizing effect on the durability of pellets. The emissions of acidic anhydrides into the atmosphere from the combustion of pellets from waste biomass were lower for $\mathrm{NO}, \mathrm{NO}_{2}, \mathrm{NOx}$ and $\mathrm{H}_{2} \mathrm{~S}$ than emissions from the combustion of willow pellets. Obtained emission results suggest the need to further optimize the combustion process parameters.
\end{abstract}

Keywords: energy from biomass; pellets; wood waste; municipal waste

\section{Introduction}

The production of energy by burning solid fuels as the main item in energy mixes is prevalent across many countries in the world, including the largest energy producers, such as the USA, China, India and most of the European Union (EU) countries. It seems that coal fuels will remain an important element of their economies for at least several dozen years [1]. The share of energy from renewable sources in final energy consumption in the EU-28 and in Poland in 2016 was $8.0 \%$ and $8.3 \%$, respectively. In 2013-2016, there was an increase by $0.4 \%$ in the EU-28, but a decrease by $0.6 \%$ in Poland $[2,3]$. In 2016, the structure of primary energy production from renewable sources in the European Union included a share of $44.7 \%$ of solid biofuels and $4.7 \%$ of municipal waste in this stream but the results for Poland are different-70.7 and $0.9 \%$, respectively. In 2016, in the EU, solid biomass had a $15.2 \%$ share in the structure of the consumption of household energy from individual energy carriers. A smaller index has been noted in Poland, 13.5\% [3], and for the whole world, 10-14\% [4]. The $27 \mathrm{EU}$ member states have a high potential for waste biomass for energy applications, calculated at $8500 \mathrm{PJ} \cdot \mathrm{y}^{-1}$ [5]. The use of biomass for energy production has a number of advantages, such as low costs and high availability, which lowers the costs of transport and reduces its environmental impact $[4,6,7]$. It is also important that biomass can be used both in the boilers of the power industry to generate heat and electricity as small individual heating installations [8]. The market for biomass pellets is growing systematically on a global scale. As a result, woody and herbaceous biomass will be more difficult to obtain [9]. Difficulties are also noted in the access to wood and agricultural residues in many places around the world, i.e., African countries [8]. 
Large amounts of waste with a significant potential for energy production are produced by the wood industry (logging and wood processing residues) - up to $27 \%$ of the wood mass. Up to $42 \%$ of this waste can be obtained for energy purposes [8]. Poland is a country with a relative high forest residues theoretical potential in the EU [5]. This waste contains $43-51 \%$ of carbon, and the heat generated by its combustion reaches $18.5-20 \mathrm{MJ} \cdot \mathrm{kg}^{-1}$, which makes it a valuable energy material $[10,11]$. An additional advantage is the low amount of ash produced during the combustion of the wood residues, ranging from 0.4 to $2.0 \%$. The use of a mixture consisting of $80 \%$ of sewage sludge, $19 \%$ of wood dust and $1 \%$ of quicklime produced results that proved that a widespread use of this type of fuel was possible since the heat generated by its combustion was slightly over $13 \mathrm{MJ} \cdot \mathrm{kg}^{-1}$. Replacing wood dust with coal dust raised this value to $19 \mathrm{MJ} \cdot \mathrm{kg}^{-1}$. Attention is paid to the hygroscopy of this fuel and its susceptibility to crumbling under the influence of moisture [11]. Due to the high price of wood obtained from forests by the wood industry using typical methods, slash and waste material obtained by pruning trees and shrubs are used to produce pellets. Wood from short cultivation cycles of Populus, Salix, Eucalyptus and Robinia is also used [12]. This method of wood management is also used in agriculture in orchards $[13,14]$. Forest residues and straw are counted as the top two contributors of energy from the residual biomass in the EU-7000 PJ. $\mathrm{y}^{-1}$ [5]. Agriculture is the main source of fuel biomass in the world. In this context, apart from trees and shrubs, attention is paid to the cultivation of energy plants and the use of post-harvest waste for this purpose [6]. Among agricultural crops, the typical biomass used for energy production are cereals, miscanthus, mallow, rapeseed, sunflower, and Jerusalem artichoke, but also agricultural residues such as vine, shrub and fruit tree shoots, corn stalks, peanut and hickory shells [14-16]. According to Hamelin et al.'s elaboration, the straw theoretical potential in Poland is high compared with many other EU-27 countries [5]. Pellets from vine shoot biomass have a standard calorific value for a majority of biomass types-18 MJ $\cdot \mathrm{kg}^{-1}$ [14]. Due to the large diversity of agricultural crops and residues, the possibility of their recovery for energy purposes varies from 19 to $75 \%$ of the total mass [8].

The third of the important biomass sources for modern energy production, after wood and agricultural products, is municipal waste. Solid municipal waste (residues from urban green areas, roadside vegetation, food, paper, textile) and sewage sludge are used for energy production, both as homogeneous fuels, as well as in mixtures with other biomass for co-combustion with coal. There is a lot of information about the difficulties in the management of municipal waste due to the significant differentiation of their properties [17]. Chen et al. [18] suggested using fuel in the form of granules from sewage sludge and wood dust in a proportion of 10:1, with a moisture content of $14.2-18.5 \%$, in the form of granules with a diameter of 2 and $7 \mathrm{~mm}$. The results (a calorific value of 21.8-23.4 MJ.kg-1) were favorable and the fuel proved to meet the requirements of the Taiwanese company Taipower. Also, Jiang et al. [19] mentioned sewage sludge as an interesting material that could be a biomass binder in the production of pellets. According to these authors, the addition of sewage sludge reduces the energy needed to compress and extrude materials during the production of pellets, increases the density and hardness of pellets (reducing dust during transport and operation) and improves combustion parameters. The downside is an increase in the weight of combustion residues in comparison to pure wood and herbaceous biomass. Stabilized sewage sludge contains $40-70 \%$ of carbon in its dry matter, which means that these materials could be used for energy production [20,21]. Nevertheless, the process of preparing sewage sludge for combustion and co-combustion is so expensive that the rolling costs of this type of use are not very favorable-in Poland, $375-438 €$ for $1 \mathrm{Mg}$ d.m., compared to 75-150 in agriculture and reclamation [20]. An additional problem is the amount of ash generated from this material, which is greater than in the case of most other fuels-an average of $36.4 \%$ for sewage sludge as against approx. $1 \%$ for wood, $6 \%$ for wheat straw and $19-22 \%$ for coal $[22,23]$. Therefore, the co-combustion of sewage sludge should be redefined to find an innovative method for the preparation of this material before its use for energy production. Apart from energy production, the new material has to give end users measurable financial benefits in the form of better furnace operating parameters. Yilmaz et al. [24] showed that the best results could be obtained by 
burning pellets with a size of $35 \mathrm{~mm}$ made from waste from plant oil production and sewage sludge. These authors noticed the high susceptibility of pellets to mechanical degradation under the influence of moisture and, for this reason, they recommended short-term storage under conditions that would counteract the moistening of the material. Jiang et al. [25] showed that better results could be obtained by burning pellets made from a mixture of sewage sludge and wood biomass than sewage sludge alone. As far as energy production is concerned, pellets are much more efficient than raw biomass. Increasing biomass density reduces transport costs and improves combustion parameters [26]. When pellets are formed, it is possible to control their composition, and when they are finally used, it is possible to automatically feed them to the furnace.

In the literature, there is little mention of the process of granulation/pelletization of energy materials with the use of municipal waste. Relatively few tests of this type have been conducted on sewage sludge for only a couple of years. Li et al. [27] presented optimum parameters for the production of pellets from biomass and sewage sludge $(50+50 \%)$ : pressure $55 \mathrm{MPa}$, temperature $90{ }^{\circ} \mathrm{C}$ and moisture in the material $10-15 \%$. The energy needed to produce pellets using sewage sludge was $50 \%$ lower than the energy needed to produce pellets from pure biomass. Similar moisture parameters of material intended for pelletization were reported by Kliopova and Makariski [28]. Kijo-Kleczkowska et al. [23] obtained pellets with densities of $\left(\mathrm{kg} / \mathrm{m}^{3}\right.$ ): 1089.2 (hard coal), 859.9 (sewage sludge), 802.6 (lignite), 363.1 (Salix viminalis), 898.1 (50\% sewage sludge $+50 \%$ hard coal), 803.5 (50\% sewage sludge $+50 \%$ brown coal), and 515.9 ( $50 \%$ sludge $+50 \%$ Salix viminalis). There were a number of changes in the process of combustion of particular solid biofuels after the addition of sewage sludge. Jiang et al. [19] analyzed the possibilities of pelleting energy materials using sewage sludge and noticed an increase in the density of pellets obtained while increasing pressure to $28,41,55,69$ and $83 \mathrm{MPa}$. A further increase in pressure to $110 \mathrm{MPa}$ no longer caused any significant differences. The increase in density and hardness of pellets was also the resultant of the share of sewage sludge (from 20 to $80 \%$ ). The temperature during pelletization should not exceed $110{ }^{\circ} \mathrm{C}$, and the content of moisture in the input material should not exceed $15 \%$. Higher temperatures and humidity reduce the density of pellets. If granulates/pellets based on limed sludge and other selected solid waste are to be used for co-combustion with biomass in heating furnaces, it is necessary to prepare a production technology that will make them easy to produce repeatedly and make them profitable to producers, easy to transport, easy to use precisely, effective during biomass combustion and safe. They should also generate ash that is easy to remove from furnaces and environmentally safe. García-Maraver et al. [29] noticed that the process of the preparation of heating pellets and their physical, physicochemical and chemical properties had a significant impact on the combustion process and emission parameters. Lehtikangas [30] stated that it was necessary to use physically stable materials in the combustion process due to the possibility of disturbing the operation of automatic fuel feeders and advanced systems of automatic furnace control by dust. Moreover, this author noted that the temperature in the furnace could increase significantly (due to the combustion of dusts), which would lead to the melting of combustion residues. According to Sarenbo and Claesson [31], the production of granulate has to be effective, the granulate binder must not adversely affect the properties of the whole aggregate, and the final chemical composition and stability of the aggregate has to be consistent with the recommendations for a particular type of use for the material. Thus, the problem arises of developing a technology that will make it possible to produce granulates/pellets with the desired characteristics and properties. During previous research projects dealing with the granulation/pelletization of materials, the problem of the durability of products and their homogeneity was noted.

Emissions from the combustion of carbonaceous materials may be an obstacle to a wider use of biomass for energy production [7]. In this respect, attention is paid to the emission of $\mathrm{CO}_{2}$ to the atmosphere as one of the main gases affecting the greenhouse effect. Nevertheless, in comparison to the combustion of solid fossil fuels, the combustion of biomass leads to a reduction in $\mathrm{CO}_{2}$ emissions to the atmosphere when co-combustion technology is used [6,16]. As far as the so called carbon footprint is concerned, biomass is neutral to carbon circulation in the environment [10]. Biomass combustion 
also results in the emission of gases other than $\mathrm{CO}_{2}$ (including $\mathrm{NOx}, \mathrm{CO}, \mathrm{SO}_{2}$, hydrocarbons) as well as dust polluting the atmosphere, especially when combustion does not take place in optimum conditions. It is often mentioned in the literature that the emission of these gases to the atmosphere could be reduced by mixing fuel with lime and lime and dolomite dust, which in terms of chemical properties are mainly calcium compounds: $\mathrm{CaCO}_{3}, \mathrm{CaO}, \mathrm{Ca}(\mathrm{OH})_{2}[7,31-33]$.

The study was carried out in a region with the largest forest cover in Poland $-49.3 \%$ of the total area and $51.7 \%$ of the land area of the region, compared to $30.5 \%$ for the whole country. The wood industry plays one of the key roles in its economy-wood acquisition amounts to $3.6 \mathrm{kdam}^{3}$ per year [34]. Data on municipal waste management show that the amount of municipal waste that is combusted is still small, amounting to $19.4 \%$ of the total waste stream in the Lubusz region, compared to $24.4 \%$ in Poland [35]. Counting the current energy production from biomass in Poland in relation to the theoretical potential of this source (20-30\% of the final energy consumption [5]), there is still a large reserve for activities intensifying this process. The use of waste from the wood industry as a fuel material allows to reduce the amount of this waste and reduce the energy demand from conventional sources. This approach also reduces the use of natural resources while meeting the energy needs of the population, so socio-environmental systems would be sustainable [36]. In order to further develop the thermal management of waste biomass, it is necessary to solve problems related to the emission of pollutants into the atmosphere. The aim of this study was to show the possibility of using waste generated in this region in large quantities as a renewable energy source. In many wastewater treatment plants, sewage sludge is still hygienized with lime. Materials prepared in this way are usually used as a soil improver. Therefore, the question was asked whether it could also be used as an improver in the biomass combustion process. For this purpose, it was considered whether it would be possible to use waste from the wood industry and limed municipal sewage sludge to produce solid fuel in the form of pellets with good thermal properties and at the same time ecologically safe. It was hypothesized that the addition of limed sewage sludge to fuel made from biomass would reduce the emission of such gases as acidic anhydrides.

\section{Materials and Methods}

A number of tests were carried out to find out whether it would be possible to produce durable pellets with good thermal properties from waste biomass. They included:

- Evaluation of input waste materials available in the region in large quantities;

- Preparation of mixtures of input materials and checking their thermal properties;

- Preparation of pellets from selected materials with the best properties in two groups-with lime and without lime;

- Testing pellet durability under high humidity conditions;

- Burning pellets under controlled conditions;

- The input materials for the tests were: straw, wood shavings, wood dust and sewage sludge hygienized with lime;

- Straw (S) - raw material obtained from a producer of straw pellets, homogeneous, crushed to a fraction of approx. $2 \mathrm{~cm}$ in length and packed in 10-kg bags; $100 \mathrm{~kg}$ of material was obtained for the needs of the experiments;

- Wood shavings (WS) - raw material obtained from a carpenter's workshop, material from debarked wood, non-homogeneous fraction from 1.5 to $3.5 \mathrm{~cm}$; the material was not additionally sieved for the tests; $100 \mathrm{~kg}$ of material was obtained for the needs of the experiments;

- Wood dust (WD)—raw material obtained from a carpenter's workshop, material from debarked wood, homogeneous fraction, powder; the material was not additionally sieved for the tests; $100 \mathrm{~kg}$ of material was obtained for the needs of the experiments;

- Sewage sludge (SS)—from the Krosno Water Utility Company Ltd. (Krośnieńskie Przedsiębiorstwo Wodociagowo-Komunalne Sp. z o.o.); municipal sludge treated with lime in an innovative 
installation for simultaneous hygienization and granulation of sewage sludge, using lime $(\mathrm{CaO})$ in a sediment to a lime ratio of 1:0.9 by weight; the material was pre-screened through a 3-mm mesh sieve; the subscreen fraction was taken for testing; $100 \mathrm{~kg}$ of the material was obtained for the needs of the experiments.

For transport to the research place, the materials were packed in plastic bags, which were opened on the spot to avoid the phenomenon of organic material thermal degradation.

Each material was pre-homogenized to obtain a homogeneous mass with average properties. The homogenization process was carried out by hand, using a table for mixing substrates onto which a particular material was poured from the transport packaging. Each material was mixed for about $10 \mathrm{~min}$. At the end of the homogenization process, 102 samples of materials (34 variants, 3 repetitions, $100 \mathrm{~g}$ each sample) were taken for laboratory analysis. In each case, the method of average pooled samples was used. The mixed samples consisted of 30 individual samples taken from the entire volume of the material.

The materials were analyzed in laboratory conditions in terms of:

- bulk density-by weight in 5 repetitions, from which the mean and standard deviations were calculated;

- the calorific value-using a calorimetric bomb Parr 6100, acc. to norm PN-C-04375-2:2013-07, in 3 repetitions, from which the mean and standard deviations were calculated;

- the total carbon content-using the Pregla-Dumas method, the samples were combusted in a pure oxygen environment and the resulting exhaust gases were automatically measured using a CHNS/O 2400 Series II PerkinElmer elemental analyzer. The measurements were conducted for weights of $1.5-2.5 \mathrm{mg}$ in three repetitions, from which the mean and standard deviations were calculated;

- the content of heavy metals $(\mathrm{Cd}, \mathrm{Cr}, \mathrm{Cu}, \mathrm{Ni}, \mathrm{Pb}$ and $\mathrm{Zn})$ was measured using the ICP-OES method and a Perkin Elmer ICP-OES Optima 8000 spectrometer, after wet mineralization in concentrated nitric acid in a Perkin Elmer Titan microwave mineralizer, in three repetitions from which the mean and standard deviations were calculated;

- the content of K, Na, Ca, Mg and Fe by ICP-OES was measured using a Perkin Elmer ICP-OES Optima 8000 spectrometer, after wet mineralization in concentrated nitric acid in a Perkin Elmer Titan microwave mineralizer, in three repetitions from which the mean and standard deviations were calculated;

- $\quad \mathrm{pH}-$ potentiometrically in a mixture of solid material (air dry) and water in a proportion of 1:5 using a pH-meter InoLab, with a WTW SenTix 41 glass electrode.

In order to obtain a homogeneous material, the samples were homogenized by grinding.

In laboratory conditions, mixtures of input materials were prepared and further components were weighed as shown in Table 1. Each mixture was ground to obtain completely equal properties before further analysis.

Table 1. Composition of the mixtures of materials.

\begin{tabular}{ccc}
\hline Mixture Number & Composition of Components & Proportion of Components \\
\hline M1 & WS + WD & $1: 1$ \\
M2 & WS + S & $1: 1$ \\
M3 & WS + SS & $1: 1$ \\
M4 & WD + S & $1: 1$ \\
M5 & WD + SS & $1: 1$ \\
M6 & S + SS & $1: 1$ \\
\hline
\end{tabular}


Table 1. Cont.

\begin{tabular}{ccc}
\hline Mixture Number & Composition of Components & Proportion of Components \\
\hline M7 & WS + WD + S & $1: 1: 1$ \\
M8 & WS + WD & $4: 1$ \\
M9 & WS + S & $4: 1$ \\
M10 & WS + SS & $4: 1$ \\
M11 & WD + SS & $4: 1$ \\
M12 & S + SS & $4: 1$ \\
M13 & WS + SS & $9: 1$ \\
M14 & WD + SS & $9: 1$ \\
M15 & S + SS & $9: 1$ \\
M16 & WS + WD + SS & $7: 2: 1$ \\
M17 & WS + S + SS & $7: 2: 1$ \\
M18 & WS + WD + SS & $3: 1: 1$ \\
M19 & WS + S + SS & $3: 1: 1$ \\
M20 & WS + WD + SS & $6: 1: 3$ \\
M21 & WS + S + SS & $6: 1: 3$ \\
M22 & WS + SS & $7: 3$ \\
M23 & WD + SS & $7: 3$ \\
M24 & S + SS & $7: 3$ \\
M25 & WS + WD + S + SS & $3: 3: 3: 1$ \\
M26 & WS + WD + S + SS & $1: 1: 1: 2$ \\
M27 & WS + WD + S + SS & $1: 1: 1: 1$ \\
M28 & WS + WD + S + SS & $3: 3: 3: 11$ \\
M29 & WS + WD + S + SS & $1: 1: 1: 7$ \\
M30 & WS + WD + SS & $3: 3: 4$ \\
\hline Note: S-straw WS-wood shavings WD- wood dust SS— & Wewage sludge.
\end{tabular}

Each mixture was analyzed in laboratory conditions in terms of:

- the calorific value-calorimetrically in three repetitions, from which the mean and standard deviations were calculated;

- $\quad \mathrm{pH}$ - potentiometrically in a mixture of solid material (air dry) and water in a proportion of 1:5 using a pH-meter InoLab, with a WTW SenTix 41 glass electrode;

- electrical conductivity (EC) — conductometrically in a mixture of air-dry solid material and water in a proportion of 1:5; using a Eutech Instruments Cyberscan PC300 and Elmetron CPC-411 devices with an EC-60 conductivity sensor;

- the subtotal content of selected components-after the hot dissolution of substrate samples (in a Perkin Elmer MPS microwave oven) in a mixture of hydrochloric and nitric acid (aqua regia), using the ICP-OES method (Perkin Elmer Optima 8000)—ISO 11466 (1995);

- the total carbon content-using the Pregla-Dumas method, the samples were combusted in a pure oxygen environment, and the resulting exhaust gases were automatically measured using a CHNS/O 2400 Series II PerkinElmer elemental analyzer. The measurements were conducted for weights of $1.5-2.5 \mathrm{mg}$ in three repetitions, from which the mean and standard deviations were calculated.

Based on the results of these analyses, mixtures expected to bring the best results in terms of energy production were selected. A total of $10 \mathrm{~kg}$ of each selected mixture were prepared for pelleting. A pelletizer, ZLSP200, $7.5 \mathrm{~kW}$ made by Eko-Pal, with a capacity of approx. $80-100 \mathrm{~kg} \mathrm{~h}^{-1}$ was used for pelleting. The input materials were mixed in the right proportions and brought to a humidity of $12-13 \%$. After wetting, the mixtures used for pelletization were rested for $24 \mathrm{~h}$. A matrix with a diameter of $6 \mathrm{~mm}$ was used in the process of pelletization. The matrix was not lubricated with any substances. During this process, the rotation speed of the pelletizer was not regulated, and only the pressure of the roller on the matrix was corrected for better performance. Each of the mixtures intended for pelletization was passed through the device until pellets of the right quality had been obtained-in 
some cases, the process was repeated three times. After the pellets were obtained, the output material was rested for $24 \mathrm{~h}$ before packing. After each of the individual mixtures was pelletized, oat husks were passed through the pelletizer to clean the sieve before working with the next mixture. Each time, the first batch of pellets obtained from a new mixture was also discarded in order to get rid of the remnants of the oat husks in subsequent completed mixtures.

The pellets were combusted in fully controlled conditions to obtain information about the combustion process and exhaust emissions. The pellets were combusted in a prototype FORST boiler equipped with two burners: 24 and $48 \mathrm{~kW}$ (modified Forster Heizkessel, PE40 boiler), adapted for burning biomass, with an automatic pellet feeding and ash removal system. Combustion of individual pellets was carried out after preheating the furnace to its optimal temperature, using a standard willow tree pellet. Each of the test pellets was fed to the boiler for $4 \mathrm{~h}$. The main combustion parameters: incineration temperature $700-800^{\circ} \mathrm{C}$, air flow $20 \mathrm{~m}^{3} \mathrm{~h}^{-1}$, mass fuel consumed $1,5 \mathrm{~kg} \cdot \mathrm{h}^{-1}$, exhaust gas temperature $141-162{ }^{\circ} \mathrm{C}$, exhaust gas mass flow $30 \mathrm{~g} \cdot \mathrm{s}^{-1}, \mathrm{O}_{2}$ in exhaust gas $11-14 \%$, max. operating temperature $90^{\circ} \mathrm{C}$, max. operating pressure $2.5 \mathrm{bar}$, pellet calorific value $17.73 \mathrm{MJ} \cdot \mathrm{kg}^{-1}$, pellet residual moisture $8-9 \%$, and ash production $3.84 \%$ of the pellet mass. The biomass boiler was included into the heat production and distribution system at the Laboratory of Thermal Technologies in the Renewable Energy Center (REC). The laboratory research system is equipped with an advanced measuring system based on measuring devices made by $\mathrm{E} \& \mathrm{H}$. The exhaust duct of the boiler is equipped with a measuring connection for chemical analysis of exhaust gases. Measurement data are registered by the building management system, Building Management System (BMS), using the Wonderware System Platform. Exhaust gas was measured continuously using a TESTO $350 \mathrm{Xl}$ exhaust gas analyzer. Emission measurements were conducted after the combustion conditions were stabilized, i.e., in the so called high-temperature combustion phase [37].

The following analyses of the pellets were performed in laboratory conditions:

- $\quad$ static and dynamic tests of moisture absorption by the pellets;

- test of the mechanical strength of the pellets;

- $\mathrm{pH}$ and EC analyses of water extracts after $48 \mathrm{~h}$ of incubation.

The static test of moisture absorption was carried out in 250-ml glass flasks. An amount of $10 \mathrm{~g}$ of pellets were poured into a flask and $90 \mathrm{~cm}^{3}$ of distilled water were added. After $48 \mathrm{~h}$ of incubation at room temperature, the samples were subjected to gravity dehydration on sterile gauze for $10 \mathrm{~min}$. After that, a visual evaluation of the disintegration was carried out, the pellets were weighed and the leachate was collected to the volumetric flasks, then the mechanical strength of the pellets was examined.

The dynamic moisture absorption test was carried out in $250-\mathrm{cm}^{3}$ plastic bottles. An amount of $10 \mathrm{~g}$ of pellets were poured into the bottles and $90 \mathrm{~cm}^{3}$ of distilled water was added. The samples were shaken on a mechanical stirrer at $60 \mathrm{rpm}$ for $1 \mathrm{~h}$ and they were left for $24 \mathrm{~h}$ at room temperature. After $24 \mathrm{~h}$, the samples were again subjected to mechanical shaking at $60 \mathrm{rpm}$ for $1 \mathrm{~h}$. The pellets were then subjected to gravity dehydration on sterile gauze for $10 \mathrm{~min}$. Decomposition was assessed visually, the pellets were weighed, and the amount of leachate was measured using the method of quantitative gathering to the volumetric flasks. Then, the mechanical strength of the pellets was examined.

Due to the disintegration of some of the pellets during the static and dynamic tests, mechanical strength was tested only in the samples that did not disintegrate. The study consisted in dropping each pellet from a height of $1.5 \mathrm{~m}$ onto a concrete surface and a visual assessment of disintegration.

The $\mathrm{pH}$ and electrical conductivity test was carried out in water solutions obtained by gravitational drainage of the pellets, $\mathrm{pH}$ was measured potentiometrically (using a WTW Inolab ph level $1 \mathrm{pH}$ meter, with a WTW SenTix 41 glass electrode) in the supernatant of a 1:2.5 dry solid material: water suspension and EC was measured conductometrically (using a Cyberscan PC300 Series conductor) in the water-saturated paste. In the samples that completely disintegrated, $\mathrm{pH}$ and 
electrical conductivity were measured in the suspension and in the leachate obtained by mechanical filtration of the suspension.

\section{Results and Discussion}

\subsection{Initial Observations}

Although the materials used in this study consisted of waste generated on a large scale by industrial and municipal plants, they were morphologically balanced (Figure 1). While mixing the input materials, it was observed that large amounts of dust appeared during the process of mixing wood dust and limed sewage sludge with other materials. This will certainly be a problem both during the transport of these materials to the sites where mixtures and pellets will be prepared, as well as during the preparation of the products themselves. Nevertheless, the use of materials with a diversified structure promised well for the formation of pellets. By using particles of varying equivalent diameter, fiber length and shape, a compact mass of the mixture can be obtained. As a result, the pellets should have a higher bulk density and mechanical durability.

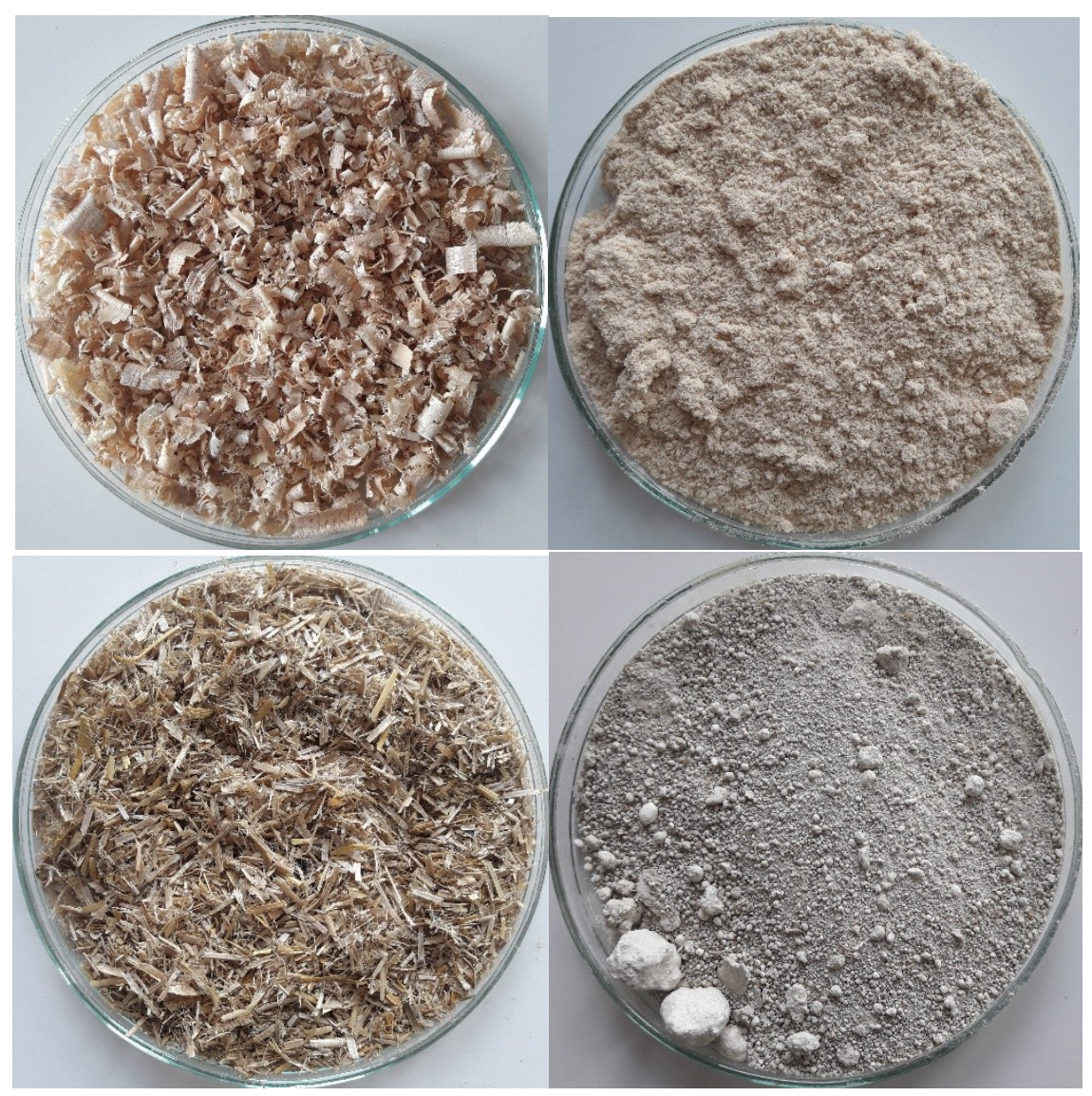

Figure 1. Input materials used in the study—-wood shavings, wood dust, straw and limed sewage sludge.

\subsection{Properties of the Input Materials}

For subsequent input materials, the following bulk density values were obtained (mean \pm standard deviation): WS-110 $\pm 5.4 \mathrm{~kg} \cdot \mathrm{m}^{-3}, \mathrm{WD}-172 \pm 5.0 \mathrm{~kg} \cdot \mathrm{m}^{-3}, \mathrm{~S}-85 \pm 2.2 \mathrm{~kg} \cdot \mathrm{m}^{-3}, \mathrm{SS}-845 \pm 4.7 \mathrm{~kg} \cdot \mathrm{m}^{-3}$.

This is important information because of the need to transport the materials to the site where they will be utilized. Since the materials will eventually be combusted, it is essential that with the relatively low bulk density of straw and wood shavings, the limiting criterion for transport will be the volume of material that can safely be loaded onto a transport vehicle-without the risk of uncontrolled scattering. 
Although wood dust has the highest bulk density among these materials, it will also be problematic in transport because it generates large amounts of dust.

All biomass materials used in this study had a similar carbon content-from 48 to $53 \%$ of dry mass. The content of dry matter in them was also similar-within 90-92\%. Sewage sludge hygienized with lime was a significantly different material; its carbon content was approx. $14 \%$ with $76 \%$ of dry matter. The $\mathrm{pH}$ analysis showed that the $\mathrm{pH}$ of straw was slightly alkaline, the $\mathrm{pH}$ of sewage sludge hygienized with lime was strongly alkaline, and the $\mathrm{pH}$ of the other materials-wood shavings and wood dust-was acidic (Table 2). The potassium content was clearly higher in the straw than in the other analyzed components. Straw was also characterized by a higher content of calcium than wood shavings and wood dust. Of course, the sewage sludge hygienized with lime has outperformed the remaining materials in this respect many times. Sewage sludge involves considerably higher contents of $\mathrm{Fe}, \mathrm{Cr}, \mathrm{Cu}, \mathrm{Ni}$, and $\mathrm{Zn}$ than other materials (Table 2).

Table 2. Selected physical and physic-chemical properties of the input materials.

\begin{tabular}{|c|c|c|c|c|c|c|c|c|c|c|c|c|c|c|}
\hline \multirow{2}{*}{ Material } & $\mathrm{C}$ & Dry Mass & \multirow{2}{*}{$\mathrm{pH}-\mathrm{H}_{2} \mathrm{O}$} & $\mathbf{K}$ & $\mathrm{Ca}$ & $\mathrm{Mg}$ & $\mathrm{Na}$ & $\mathbf{F e}$ & $\mathrm{Cd}$ & $\mathrm{Cr}$ & $\mathrm{Cu}$ & $\mathrm{Ni}$ & $\mathrm{Pb}$ & Zn \\
\hline & & $(\%)$ & & \multicolumn{11}{|c|}{$\mathrm{mg} \cdot \mathrm{kg}^{-1}$} \\
\hline WS & 49.1 & 92.5 & 5.1 & 287 & 364 & 101 & 13 & nd & nd & nd & nd & nd & 0.8 & 4.0 \\
\hline WD & 52.8 & 92.0 & 5.5 & 234 & 298 & 82 & 11 & nd & nd & nd & nd & nd & 0.7 & 3.3 \\
\hline $\mathrm{S}$ & 48.0 & 89.8 & 8.0 & 2180 & 1109 & 120 & 5 & 16 & nd & nd & nd & nd & nd & 3.0 \\
\hline SS & 13.9 & 76.0 & 12.4 & 307 & 75,700 & 348 & 48 & 433 & nd & 1.5 & 14 & 0.7 & 0.9 & 44.7 \\
\hline
\end{tabular}

Similar results were presented by Houshfar et al. [10]. They indicated that the average content of carbon was $51.4 \%$ for wood pellets, $53.4 \%$ for wood waste and $49.5 \%$ for straw. A significantly higher content of $C$ in sewage sludge was reported in the literature-28.4\% [37], 48.9\% [10], 53-60\% [21]. However, in contrast to this study, that sewage sludge was not limed. In these analyses, we also obtained a dry mass of wood material and straw similar to that presented in the analyses of the cited authors-90.4-93.5\% and 88.3\%, respectively [6]. However, the dry mass of sewage sludge was smaller than presented in the literature. Chen et al. [38] indicated a content of $91.5 \%$ of dry matter for sun-dried sediments, but this is only $16-19 \%$ of the mass of raw sewage sludge as determined by Pulka et al. [21].

For subsequent input materials, the following calorific values were obtained (mean \pm standard deviation):

- WS- $16883 \pm 755 \mathrm{~kJ} \cdot \mathrm{kg}^{-1}\left(4029 \pm 180 \mathrm{kcal} \cdot \mathrm{kg}^{-1}\right)$

- WD-14550 $\pm 1027 \mathrm{~kJ} \cdot \mathrm{kg}^{-1}\left(3473 \pm 245 \mathrm{kcal} \cdot \mathrm{kg}^{-1}\right)$

- $\quad \mathrm{S}-18549 \pm 753 \mathrm{~kJ} \cdot \mathrm{kg}^{-1}\left(4427 \pm 180 \mathrm{kcal} \cdot \mathrm{kg}^{-1}\right)$

- SS-no data (the material did not burn)

The analysis of the calorific value of the input materials showed the highest value for straw (by $11.3 \%$ higher than the mean for the materials analyzed), lower for wood shavings ( $1.3 \%$ higher than the mean for the materials analyzed), whereas for wood dust it was lower by $12.7 \%$ than the mean for the materials analyzed. The calorific value of the materials indicated that the most promising ones at this stage appeared to be straw and wood shavings. Due to the high content of minerals in the limed sewage sludge, it turned out that this material could be problematic as a fuel additive. The results for wood biomass and straw are typical as compared to those described widely in the literature, where calorific values within $16.5-20.5 \mathrm{MJ} \mathrm{kg}^{-1}[33,39,40]$ are most frequently recorded. The calorific value of sewage sludge is lower, amounting to $11.37 \mathrm{MJ} \cdot \mathrm{kg}^{-1}$ [38], but always for non-limed sewage sludge.

\subsection{Properties of Fuel Mixtures}

It was noted that the addition of sewage sludge hygienized with lime had a significant impact on the $\mathrm{pH}$ of materials, the content of dry matter and content of total carbon (TC). The content of dry matter and total carbon are important properties in terms of the combustion characteristics of solid 
fuel, and the low $\mathrm{pH}$ may additionally affect the resulting emissions. Since different input materials were used in different proportions for the preparation of subsequent mixtures, significant differences were noted in the content of carbon in the mixtures, what was expected (Table 3).

Table 3. Properties of the mixtures of materials.

\begin{tabular}{|c|c|c|c|c|c|c|c|c|c|c|c|c|c|c|}
\hline \multirow{2}{*}{ Material } & TC & Dry Mass & \multirow{2}{*}{$\mathrm{pH}$} & K & $\mathrm{Ca}$ & $\mathrm{Mg}$ & $\mathrm{Na}$ & $\mathrm{Fe}$ & $\mathrm{Cd}$ & $\mathrm{Cr}$ & $\mathrm{Cu}$ & $\mathrm{Ni}$ & $\mathrm{Pb}$ & $\mathrm{Zn}$ \\
\hline & & $\%$ & & \multicolumn{11}{|c|}{$\mathrm{mg} \cdot \mathrm{kg}^{-1}$} \\
\hline M1 & 50.9 & 92.2 & 5.4 & 521 & 662 & 183 & 24 & $\mathrm{n} / \mathrm{a}$ & $\mathrm{n} / \mathrm{a}$ & $\mathrm{n} / \mathrm{a}$ & $\mathrm{n} / \mathrm{a}$ & $\mathrm{n} / \mathrm{a}$ & 1.49 & 7.33 \\
\hline M2 & 48.1 & 91.3 & 5.7 & 2094 & 1490 & 170 & 10 & 8 & $\mathrm{n} / \mathrm{a}$ & 0.21 & $\mathrm{n} / \mathrm{a}$ & n/a & 0.56 & 6.50 \\
\hline M3 & 28.1 & 87.2 & 12.3 & 598 & 74,571 & 396 & 55 & 430 & $\mathrm{n} / \mathrm{a}$ & 1.36 & 12.56 & 0.56 & 1.55 & 44.57 \\
\hline M4 & 51.4 & 91.9 & 9.7 & 2788 & 1390 & 252 & 23 & 24 & $\mathrm{n} / \mathrm{a}$ & $\mathrm{n} / \mathrm{a}$ & $\mathrm{n} / \mathrm{a}$ & $\mathrm{n} / \mathrm{a}$ & 0.22 & 7.09 \\
\hline M5 & 30.3 & 86.3 & 11.4 & 537 & 77,432 & 482 & 65 & 436 & 0.02 & 1.58 & 14.54 & 0.76 & 1.62 & 52.07 \\
\hline M6 & 28.4 & 86.5 & 12.3 & 3159 & 53,465 & 428 & 43 & 352 & $\mathrm{n} / \mathrm{a}$ & 0.65 & 8.27 & 0.14 & 0.79 & 33.23 \\
\hline M7 & 51.1 & 92.6 & 6.4 & 1460 & 1068 & 216 & 13 & 8 & 0.00 & 0.17 & $\mathrm{n} / \mathrm{a}$ & $\mathrm{n} / \mathrm{a}$ & 0.82 & 6.35 \\
\hline M8 & 51.0 & 93.4 & 5.1 & 536 & 692 & 139 & 17 & $\mathrm{n} / \mathrm{a}$ & $\mathrm{n} / \mathrm{a}$ & 0.02 & $\mathrm{n} / \mathrm{a}$ & $\mathrm{n} / \mathrm{a}$ & 0.43 & 7.57 \\
\hline M9 & 49.0 & 92.2 & 5.8 & 1481 & 2075 & 162 & 9 & 14 & $\mathrm{n} / \mathrm{a}$ & $\mathrm{n} / \mathrm{a}$ & $\mathrm{n} / \mathrm{a}$ & $\mathrm{n} / \mathrm{a}$ & $\mathrm{n} / \mathrm{a}$ & 5.40 \\
\hline M10 & 42.9 & 91.3 & 12.2 & 674 & 48,413 & 314 & 40 & 295 & $\mathrm{n} / \mathrm{a}$ & 0.60 & 3.28 & $\mathrm{n} / \mathrm{a}$ & 1.46 & 22.68 \\
\hline M11 & 45.1 & 91.0 & 10.6 & 616 & 33,886 & 367 & 49 & 255 & $\mathrm{n} / \mathrm{a}$ & $\mathrm{n} / \mathrm{a}$ & 1.14 & $\mathrm{n} / \mathrm{a}$ & 0.29 & 20.71 \\
\hline M12 & 37.2 & 89.6 & 10.9 & 3423 & 30,235 & 375 & 27 & 219 & $\mathrm{n} / \mathrm{a}$ & 0.32 & $\mathrm{n} / \mathrm{a}$ & $\mathrm{n} / \mathrm{a}$ & 0.37 & 19.09 \\
\hline M13 & 46.8 & 91.9 & 12.0 & 572 & 13,453 & 159 & 16 & 107 & $\mathrm{n} / \mathrm{a}$ & $\mathrm{n} / \mathrm{a}$ & $\mathrm{n} / \mathrm{a}$ & $\mathrm{n} / \mathrm{a}$ & 0.32 & 11.27 \\
\hline M14 & 48.3 & 91.9 & 10.6 & 487 & 14,831 & 288 & 36 & 141 & 0.02 & 1.11 & $\mathrm{n} / \mathrm{a}$ & 0.02 & 6.31 & 13.64 \\
\hline M15 & 44.4 & 90.3 & 11.9 & 3243 & 13,033 & 230 & 15 & 97 & $\mathrm{n} / \mathrm{a}$ & 1.61 & $\mathrm{n} / \mathrm{a}$ & 0.28 & $\mathrm{n} / \mathrm{a}$ & 11.23 \\
\hline M16 & 46.2 & 91.8 & 11.7 & 587 & 16,868 & 177 & 20 & 139 & 0.02 & 0.48 & $\mathrm{n} / \mathrm{a}$ & 0.31 & 1.31 & 13.20 \\
\hline M17 & 45.6 & 91.4 & 11.8 & 888 & 10,835 & 142 & 13 & 61 & $\mathrm{n} / \mathrm{a}$ & $\mathrm{n} / \mathrm{a}$ & $\mathrm{n} / \mathrm{a}$ & $\mathrm{n} / \mathrm{a}$ & 0.98 & 9.12 \\
\hline M18 & 42.4 & 91.2 & 12.2 & 526 & 28,130 & 256 & 30 & 223 & $\mathrm{n} / \mathrm{a}$ & $\mathrm{n} / \mathrm{a}$ & 0.21 & $\mathrm{n} / \mathrm{a}$ & 1.06 & 21.01 \\
\hline M19 & 41.7 & 92.8 & 12.2 & 1047 & 32,961 & 264 & 27 & 280 & $\mathrm{n} / \mathrm{a}$ & 0.40 & 2.40 & 0.22 & 0.91 & 19.96 \\
\hline M20 & 37.6 & 90.7 & 12.3 & 551 & 43,583 & 287 & 34 & 333 & 0.01 & 0.44 & 1.48 & $\mathrm{n} / \mathrm{a}$ & 1.34 & 25.55 \\
\hline M21 & 37.0 & 89.9 & 12.3 & 866 & 50,099 & 359 & 39 & 418 & $\mathrm{n} / \mathrm{a}$ & 0.70 & 7.84 & 0.30 & 1.30 & 29.62 \\
\hline M22 & 38.2 & 90.7 & 12.3 & 551 & 19,318 & 157 & 19 & 86 & $\mathrm{n} / \mathrm{a}$ & $\mathrm{n} / \mathrm{a}$ & $\mathrm{n} / \mathrm{a}$ & $\mathrm{n} / \mathrm{a}$ & 0.21 & 10.58 \\
\hline M23 & 40.3 & 90.6 & 12.0 & 598 & 74,572 & 396 & 55 & 430 & $\mathrm{n} / \mathrm{a}$ & 0.42 & 3.87 & $\mathrm{n} / \mathrm{a}$ & 0.35 & 24.09 \\
\hline M24 & 37.5 & 88.0 & 11.7 & 3929 & 19,347 & 292 & 20 & 142 & $\mathrm{n} / \mathrm{a}$ & 0.04 & $\mathrm{n} / \mathrm{a}$ & $\mathrm{n} / \mathrm{a}$ & $\mathrm{n} / \mathrm{a}$ & 11.91 \\
\hline M25 & 46.2 & 91.4 & 12.0 & 1806 & 12,046 & 220 & 21 & 96 & $\mathrm{n} / \mathrm{a}$ & 0.09 & $\mathrm{n} / \mathrm{a}$ & $\mathrm{n} / \mathrm{a}$ & 0.16 & 10.67 \\
\hline M26 & 35.5 & 88.7 & 12.3 & 1323 & 52,593 & 354 & 44 & 377 & $\mathrm{n} / \mathrm{a}$ & 0.33 & 4.43 & 0.07 & 0.30 & 26.40 \\
\hline M27 & 40.5 & 90.6 & 12.3 & 1525 & 34,102 & 310 & 33 & 259 & $\mathrm{n} / \mathrm{a}$ & 0.18 & 1.50 & $\mathrm{n} / \mathrm{a}$ & 0.52 & 17.07 \\
\hline M28 & 30.2 & 87.4 & 12.3 & 835 & 79,491 & 464 & 58 & 634 & 0.00 & 1.88 & 12.91 & 0.45 & 1.14 & 42.96 \\
\hline M29 & 23.3 & 86.0 & 12.3 & 842 & 10,3626 & 491 & 65 & 720 & $\mathrm{n} / \mathrm{a}$ & 2.21 & 24.51 & 0.88 & 1.34 & 50.38 \\
\hline M30 & 35.2 & 89.4 & 12.3 & 463 & 62,336 & 364 & 45 & 431 & 0.01 & 1.29 & 8.36 & 0.55 & 1.80 & 28.70 \\
\hline
\end{tabular}

In order to use waste from the wood industry as well as agricultural and municipal waste for energy production, one of the basic research paths to take is to determine the chemical composition of these materials. In this way, it is possible to determine whether this waste contains an excessive number of components that could be dangerous to the environment. During combustion, some of them will be released from the boiler as gases, some as dust and the remaining part will be present in the ash. The presence of certain components, such as sodium, potassium, calcium, magnesium and iron, may be undesirable because they leave residue on the grate and other elements of the boiler, causing technical problems. The high content of $\mathrm{Ca}, \mathrm{Mg}, \mathrm{Na}$ and Fe resulted from the addition of sewage sludge hygienized with lime to wood as well as agricultural and organic materials (mixtures: M3, M5, M23, M28 and M29). The high content of potassium resulted from the composition of material solely based on straw or with the presence of straw in the mixtures. As far as the chemical composition of waste materials is concerned, much attention is usually paid to heavy metals. They are not transformed by combustion, so they remain unchanged in the dust and ash after the combustion process. At the same time, when organic matter burns, its input mass decreases since some of it is transformed into gaseous products and it is deprived of water, the content of heavy metals is concentrated in combustion residues and fly ashes. For this reason, the content of heavy metals in solid fuels should be low. The content of Cr was in the range of 1.11-2.21 mg. $\mathrm{kg}^{-1}$ in materials M3 (WS + SS; 1:1), M5 (WD + SS; 1:1), M14 (WD + SS; 9:1), M15 (S + SS; 9:1), M28 (WS + WD + S + SS; 3:3:3:11), M29 (WS + WD + S + SS; 1:1:1:7) and M30 (WS + WD + SS; 3:3:4). In all cases, the mixtures included sewage sludge. There was no significant $\mathrm{Cu}, \mathrm{Ni}$ and $\mathrm{Pb}$ content in all mixtures-max. $24.51 \mathrm{mg} \mathrm{Cu} \mathrm{kg}^{-1}$ in material M29, $0.88 \mathrm{mg} \mathrm{Ni}$ $\mathrm{kg}^{-1}$ in material M29 and $1.80 \mathrm{mg} \mathrm{Pb} \mathrm{kg}^{-1}$ in material M30. As far as the content of $\mathrm{Zn}$ is concerned, 
a relatively higher content was noted in mixtures M3, M5, M28 and M29, where it was in the range of $42.96-52.07 \mathrm{mg} \mathrm{kg}^{-1}$ (Table 3).

The majority of wood and agricultural waste does not contain large amounts of heavy metals. However, there are problems with their content in municipal waste. The data in Table 2; Table 3 clearly indicate the sewage sludge as a potential source of heavy metals in biomass mixtures. The content of some heavy metals $(\mathrm{Cr}, \mathrm{Ni})$ may also result from the degradation of the hardened steel elements of the screw biomass feeder, the boiler itself or the degradation of the collecting probes [17].

Since the content of carbon in raw wood and wood waste was similar, as expected, mixing these materials with each other did not cause any significant differences. This property was at similar levels to those described by other authors $[10,14,16,32]$.

The analysis of the calorific value of the mixtures showed significant differences between particular materials (Table 4). Ten highest calorific values were obtained for mixtures (in decreasing order): M1; M2; M9; M8; M4; M7; M17; M10; M19; and M13. The weakest of these mixtures reached a calorific value lower by $11.8 \%$ than the best mixture. In the case of some of the mixtures, relatively higher values of the standard deviation (5-9\%) were obtained, which indicates that the materials did not burn completely despite their homogenization: M5 (WD + SS; 1:1), M7 (WS + WD + S; 1:1:1), M11 (WD + SS; 4:1), M15 (S + SS; 9:1), M16 (WS + WD + SS; 7:2:1), M24 (S + SS; 7:3) and M27 (WS + WD + S + SS; 1:1:1:1). Most of these mixtures contained sludge in their composition, which may mean that its presence interferes with the combustion process.

Table 4. Calorific value of the mixtures of materials (value \pm SD).

\begin{tabular}{cc}
\hline Mixture No. & Calorific Value $\left(\mathbf{k J} \cdot \mathbf{k g}^{-\mathbf{1}}\right)$ \\
\hline M1 & $18,219 \pm 244$ \\
M2 & $17,755 \pm 658$ \\
M3 & $10,755 \pm 322$ \\
M4 & $17,115 \pm 153$ \\
M5 & $13,110 \pm 1134$ \\
M6 & $12,004 \pm 469$ \\
M7 & $16,843 \pm 916$ \\
M8 & $17,615 \pm 633$ \\
M9 & $17,688 \pm 90$ \\
M10 & $16,117 \pm 278$ \\
M11 & $13,815 \pm 2763$ \\
M12 & $14,330 \pm 369$ \\
M13 & $16,061 \pm 407$ \\
M14 & $15,660 \pm 154$ \\
M15 & $14,686 \pm 971$ \\
M16 & $15,692 \pm 864$ \\
M17 & $16,530 \pm 280$ \\
M18 & $15,325 \pm 129$ \\
M19 & $16,098 \pm 279$ \\
M20 & $13,612 \pm 631$ \\
M21 & $14,501 \pm 407$ \\
M22 & $13,892 \pm 468$ \\
M23 & $14,950 \pm 588$ \\
M24 & $13,847 \pm 1289$ \\
M25 & $15,810 \pm 315$ \\
M26 & $11,295 \pm 659$ \\
M27 & $12,914 \pm 1116$ \\
M28 & $7408 \pm 96$ \\
M29 & $11,366 \pm 314$ \\
M30 & \\
& \\
\hline
\end{tabular}

Sewage sludge hygienized with lime reduces the calorific value of mixtures. This is expected both due to its lower calorific value in relation to other biomass [38] and a high proportion of mineral 
compounds. The results were in the range of $7-18 \mathrm{MJ} \mathrm{kg}^{-1}$, i.e., within a typical range for different waste materials in developed countries (8.4-17 $\mathrm{MJ} \mathrm{kg}^{-1}$ ) and they were better than the results obtained in China (3-6.7 MJ kg-1) - Zhang et al. [39]. The correlation between the calorific value of the mixtures of materials and the TC content (Figure 2) and dry mass (Figure 3) was also analyzed. The calculation of correlation coefficients makes it possible to determine the linear relation between the data and at the same time to eliminate irrelevant information from the data sets [41]. The relations between the calorific value and the TC content (correlation $r=0.91)$ and the calorific value and dry mass $(r=0.86)$ were characterized by a high positive correlation. These relations, widely described in the literature [42], were expected. Ngangyo-Heya et al. [42] performed correlation analyzes for components of woody biomass without leaves, indicating the correlation of the calorific value with some of its properties. The highest positive correlation between the biomass calorific value, $\mathrm{pH}$ and lignin content have been noted.

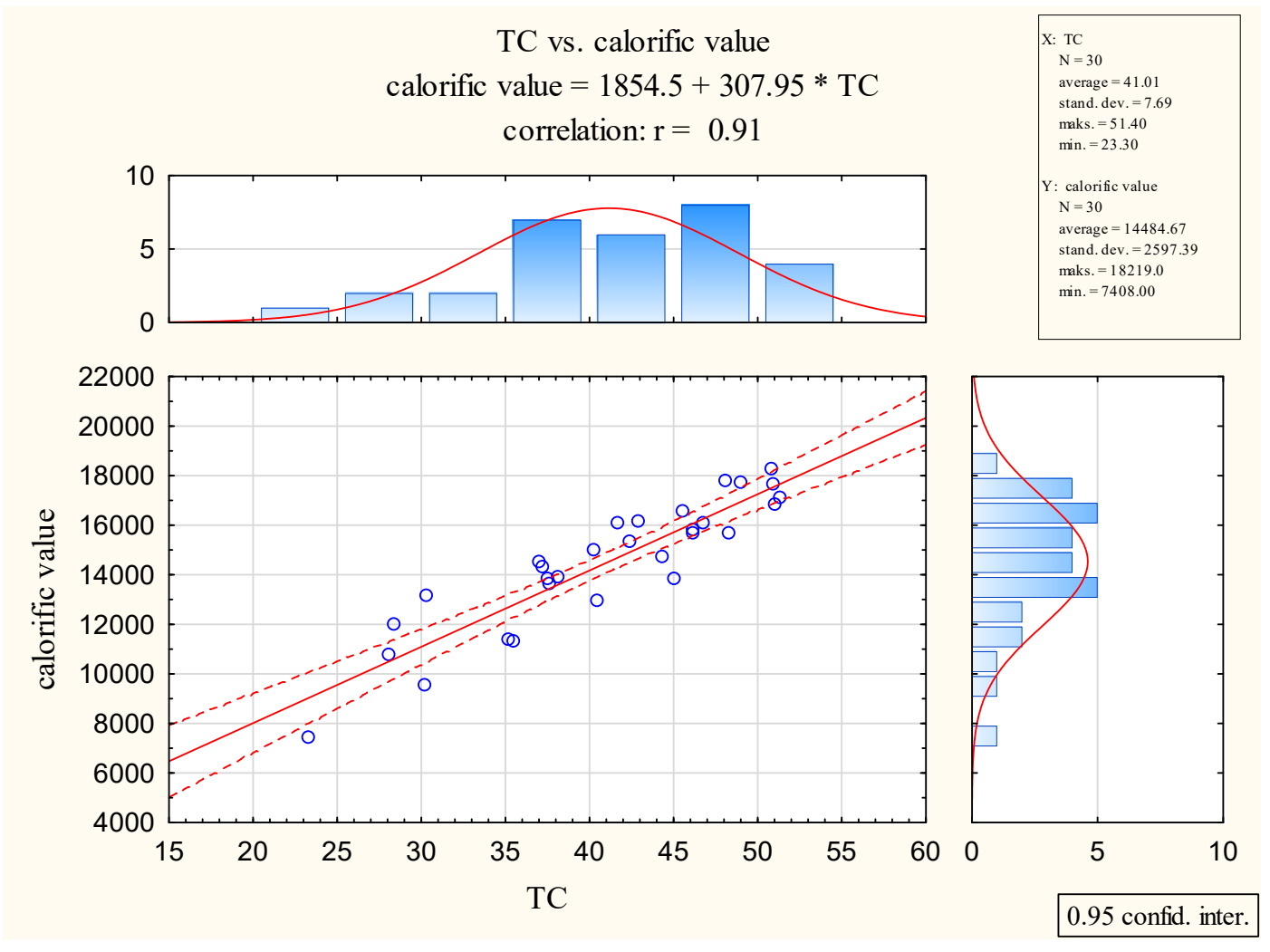

Figure 2. Graph of the correlation and dispersion of results; total carbon (TC) content vs. calorific value.

\subsection{Pellet Durability Tests}

After preliminary analyses of the input materials and mixtures, ten of them-the most promising ones, counting thermal properties (calorific value) and chemical composition (low heavy metal content)-were pelletized. In order to test the behaviour of the pellets under the influence of moisture, a static test was carried out - the reaction of the pellets in water and a dynamic test - the reaction of the pellets in water with mechanical mixing. Since it was expected that some of the components would be transferred into the solution, an analysis of the electrical conductivity (EC) and $\mathrm{pH}$ of the extracts was planned. The test results are presented in Table 5. 
dry mass vs. calorific value

calorific value $=-840 \mathrm{E} 2+1089.3 *$ dry mass

correlation: $\mathrm{r}=0.86$
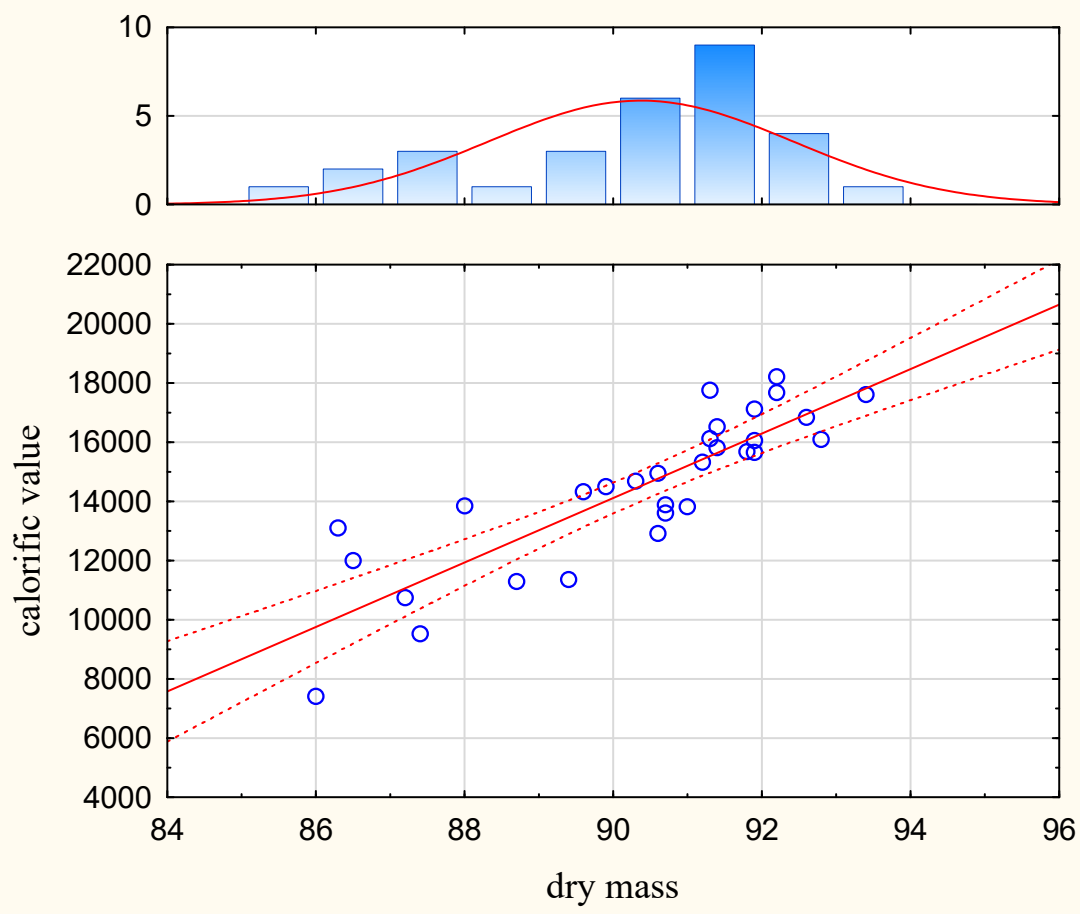
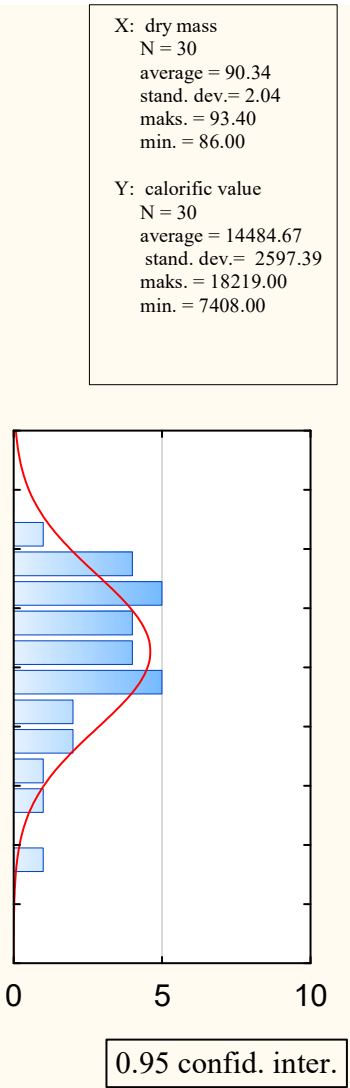

Figure 3. Graph of the correlation and dispersion of results; dry mass vs. calorific value.

Table 5. Static and dynamic test results for pellets from the selected mixtures.

\begin{tabular}{ccccccc}
\hline \multirow{2}{*}{$\begin{array}{c}\text { Material } \\
\text { Designation }\end{array}$} & \multicolumn{3}{c}{ Static Test: 2 d } & \multicolumn{3}{c}{ Dynamic Test: 1 h Mixing 1, D Rest, 1 h Mixing } \\
\cline { 2 - 7 } & Disintegration & pH & EC & Disintegration & pH & EC \\
\hline M3 & $13.552 \mathrm{~g} / 76 \mathrm{ml}$ & 12.04 & 12.04 & $14.155 \mathrm{~g} / 83 \mathrm{ml}$ & 12.26 & 7.04 \\
M10 & $18.516 \mathrm{~g} / 68 \mathrm{ml}$ & 11.96 & 2.77 & $19.563 \mathrm{~g} / 75 \mathrm{ml}$ & 11.99 & 6.26 \\
M13 & $22.040 \mathrm{~g} / 68 \mathrm{ml}$ & 9.48 & 1.98 & $26.049 \mathrm{~g} / 68 \mathrm{ml}$ & 10.05 & 3.87 \\
M17 & $30.002 \mathrm{~g} / 57 \mathrm{ml}$ & 9.07 & 1.49 & $15.442 \mathrm{~g} / 74 \mathrm{ml}$ & 9.51 & 4.00 \\
M18 & $16.521 \mathrm{~g} / 72 \mathrm{ml}$ & 11.88 & 2.62 & $15.942 \mathrm{~g} / 76 \mathrm{ml}$ & 11.54 & 6.25 \\
M19 & $19.249 \mathrm{~g} / 72 \mathrm{ml}$ & 8.73 & 2.16 & $21.016 \mathrm{~g} / 77 \mathrm{ml}$ & 9.20 & 3.97 \\
M20 & $16.069 \mathrm{~g} / 72 \mathrm{ml}$ & 12.12 & 3.05 & $16.372 \mathrm{~g} / 81 \mathrm{ml}$ & 12.15 & 6.92 \\
M22 & $16.041 \mathrm{~g} / 74 \mathrm{ml}$ & 12.10 & 2.93 & $15.114 \mathrm{~g} / 79 \mathrm{ml}$ & 12.17 & 6.89 \\
M30 & $20.636 \mathrm{~g} / 68 \mathrm{ml}$ & 12.15 & 2.95 & $15.058 \mathrm{~g} / 76 \mathrm{ml}$ & 12.21 & 6.81 \\
MD & $23.245 \mathrm{~g} / 65 \mathrm{ml}$ & 5.25 & 0.50 & $11.700 \mathrm{~g} / 67 \mathrm{ml}$ & 5.54 & 0.74 \\
\hline
\end{tabular}

Most of the pellets disintegrated under the influence of water just a few hours after being soaked. After one day, mixtures M1, M2, M4, M7, M8, M9 and M16, as well as the pellets made from the input materials WS and S, disintegrated completely.

The durability of the pellets determined in the static and the dynamic tests was the same. The most durable were the pellets from mixtures M3 (WS + SS; 1:1), M10 (WS + SS; 4:1), M18 (WS + WD + SS; 3:1:1), M19 (WS + S + SS; 3:1:1), M20 (WS + WD + SS; 6:1:3) and M22 (WS + SS; 7:3). The pellets from mixtures M17 (WS + S + SS; 7:2:1) and M30 (WS + WD + SS; 3:3:4) and from pure WD, used as the input material, retained their structure to a lesser extent. The pellets from mixture M13 (WS + SS; 9:1) lost their structure in the dynamic test but retained it in the static test. Table 6 shows the structure of the pellets after the moisture absorption tests. 
Table 6. Pellet structure after the moisture absorption tests.

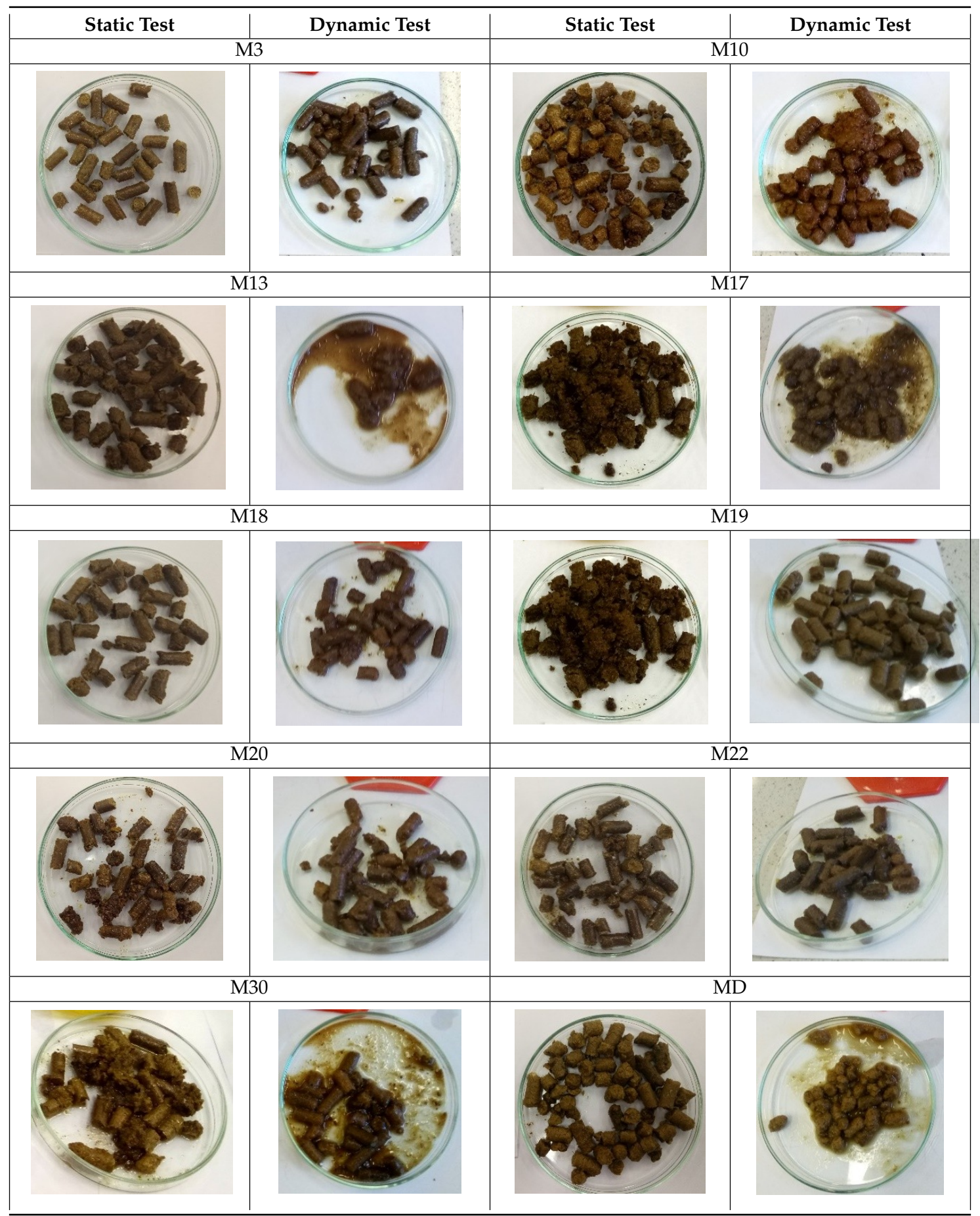

The tests showed that the combination of wood shavings (WS) with sewage sludge (SS) was good for the pellet structure. Sewage sludge hygienized with lime acted as a binder as long as it was present in the pellets in a proportion of at least $20 \%$. When its share was lower, $10 \%$, i.e., in mixture M13, the stabilization effect on the WS + SS pellets decreased significantly.

When the pellets were dropped three times from a height of $\mathrm{h}=1.5 \mathrm{~m}$, the results were as follows: the pellets from mixtures M18 (WS + WD + SS; 3:1:1), M19 (WS + S + SS; 3:1:1), M3 (WS + SS; 1:1), M22 (WS + SS; 7:3), M10 (WS + SS; 4:1) and M13 (WS + SS; 9:1) did not disintegrate. For this reason, it can be said that they should be good for transport in conditions of controlled air humidity and keep their durability. In this test, the WS + SS combinations also turned out to be the most durable. 
3.5. Examination of the Combustion Process in Terms of Emissions Including the Possibility of Eliminating Acid Anhydrides

Pellets prepared from mixtures M2 (WS + S; 0.5:0.5) and M17 (WS + S + SS; 0.7:0.2:0.1)—Figure 4-and from energy willow for comparison (EW) were used for the combustion analysis in the test boiler.

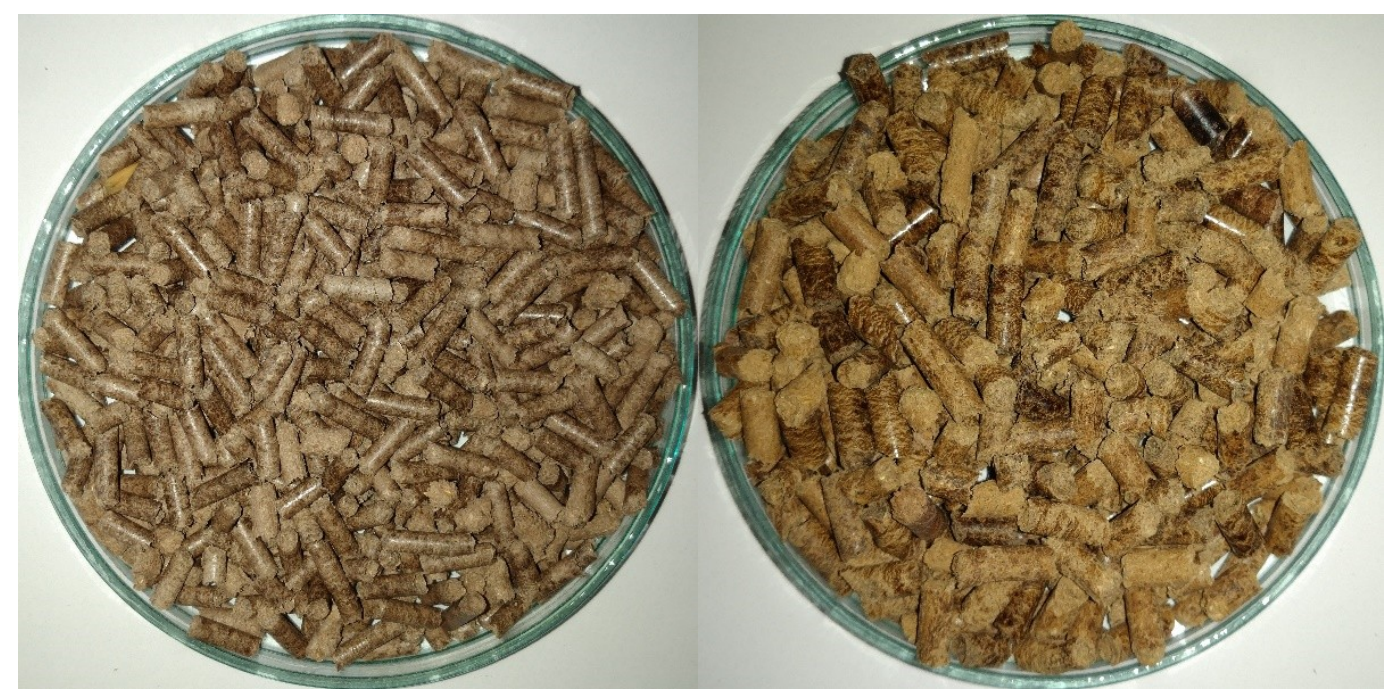

Figure 4. Pellets prepared from mixtures M2 and M17.

The results showed that it was possible to reduce exhaust emissions by the addition of limed sewage sludge to biomass fuel (Table 7).

Table 7. Exhaust emissions during the combustion of the fuels analyzed.

\begin{tabular}{|c|c|c|c|c|c|c|c|c|c|c|c|}
\hline Mixture & $\begin{array}{c}\text { Ash } \\
\text { Content }\end{array}$ & $\begin{array}{l}\text { Exhaust } \\
\text { Temp. }\end{array}$ & Pressure & Flow & $\begin{array}{c}\text { External } \\
\text { Temp. }\end{array}$ & $\mathrm{CO}$ & NO & $\mathrm{NO}_{2}$ & NOx & $\mathrm{H}_{2} \mathrm{~S}$ & $\mathbf{H}_{2}$ \\
\hline & $(\%)$ & $\left({ }^{\circ} \mathrm{C}\right)$ & (hPa) & $\left(\mathrm{dm}^{3} \cdot \mathrm{min}^{-1}\right)$ & $\left({ }^{\circ} \mathrm{C}\right)$ & \multicolumn{6}{|c|}{ (ppm) } \\
\hline M2 & 2.1 & 100 & 1002 & 0.95 & 28.9 & 310 & 36 & 0.2 & 34 & 0.8 & 33 \\
\hline M17 & 5.5 & 156 & 1000 & 0.95 & 29.0 & 144 & 46 & 0.4 & 42 & 1.5 & 0 \\
\hline WE & 1.5 & 120 & 1007 & 0.93 & 24.0 & 139 & 96 & 1.4 & 97 & 2 & 13 \\
\hline
\end{tabular}

This information on exhaust emissions makes it possible to find differences between mixture M2 (without the addition of sewage sludge) and M17 (with the addition of $10 \%$ by weight of limed sewage sludge). The results are as follows:

- reduction in $\mathrm{CO}$ emissions by $115 \%$;

- increase in $\mathrm{NO}$ emissions by $22 \%$;

- increase in $\mathrm{NO}_{2}$ emissions by $50 \%$;

- increase in $\mathrm{NO}_{x}$ emissions by $19 \%$;

- increase in $\mathrm{H}_{2} \mathrm{~S}$ emissions by $47 \%$;

- elimination of $\mathrm{H}_{2}$ emissions.

The emissions of acidic anhydrides to the atmosphere from the combustion of pellets from both mixtures (M2 and M17) were lower than from the combustion of energy willow pellets:

- $\quad \mathrm{NO}-$ by $63 \%$ for M2 and by $52 \%$ for M17;

- $\quad \mathrm{NO}_{2}$ - by $63 \%$ for M2 and by $52 \%$ for M17;

- NOx-by $63 \%$ for M2 and by $52 \%$ for M17; 
- $\mathrm{H}_{2} \mathrm{~S}-$ by $63 \%$ for $\mathrm{M} 2$ and by $52 \%$ for M17.

The decrease of $\mathrm{CO}$ content and the occurrence of the increased content of $\mathrm{NO}, \mathrm{NO}_{2}, \mathrm{NO}_{\mathrm{x}}$ and $\mathrm{H}_{2} \mathrm{~S}$ in the exhaust gases was probably influenced by the burning conditions. Important elements of process disturbance could be the addition of a mineral fraction with sewage sludge hygienized with lime. The combustion of biomass pellets resulted in the accumulation of large amounts of bottom ash and slags in the combustion chambers of the boiler, which obstructed the air supply systems in the furnace over time. In literature, this phenomenon is described as a very important negative factor connected to the use of biomass for energy production [32].

In the phase of stabilized high temperature combustion, $\mathrm{CO}$ emissions from firewood are 250-500 ppm. Significantly higher emissions occur during the boiler warming up phase, up to $16,500 \mathrm{ppm}$, and boiler quenching, $3000 \mathrm{ppm}$. Chen et al. [38] compared the combustion of coal and sewage sludge and obtained three times less $\mathrm{CO}$ emissions and two times less $\mathrm{CO}_{2}$ emissions when sewage sludge was used. This resulted in a reduction of $\mathrm{CO}$ and $\mathrm{CO}_{2}$ emissions after the addition of sewage sludge to coal and a reduction of $\mathrm{CO}_{2}$ emissions after the addition of sewage sludge to dried biomass of shiitake mushrooms. Monedero et al. [13] reported a more than 2-fold difference in $\mathrm{CO}$ emissions from the combustion of pellets from poplar wood $\left(747 \mathrm{mg} \mathrm{m}^{-3}\right)$ and pine wood $\left(331 \mathrm{mg} \mathrm{m}^{-3}\right)$. Polonini et al. [40] obtained $\mathrm{CO}$ emissions from the combustion of wood pellets that were similar to the emissions described in this study for M17 and EW pellets but by $40 \%$ lower than for M2. The concentration of oxygen in exhaust gases varies from 6 to $18 \%$ [37] depending on the phase. The composition of exhaust gases strongly depends on the conditions in which solid fuels are burnt, especially on combustion temperature and the primary excess air ratio. Under non-optimum conditions, e.g., when warming up a boiler, a gas with the following composition is formed: $\mathrm{H}_{2}, \mathrm{C}_{\mathrm{x}} \mathrm{H}_{\mathrm{y}}, \mathrm{H}_{2} \mathrm{O}, \mathrm{CO}_{2}$ and $\mathrm{N}_{2}$, and $\mathrm{NH}_{3}, \mathrm{HCN}, \mathrm{HOCN}$ and $\mathrm{NO}$ in smaller amounts [10]. As a result of complete combustion, $\mathrm{CO}_{2}$ and $\mathrm{H}_{2} \mathrm{O}$ are formed and much more NOx. However, NOx emissions are relatively lower in comparison to wood pellets containing not much nitrogen and under optimum combustion conditions-a primary excess air ratio of 0.9-0.95 [10]. The concentration of NOx increases after the addition of sewage sludge to coal and to dried biomass of shiitake mushrooms. Monedero et al. [13] indicated that there were differences in NOx emissions depending on the type of wood that is burnt-poplar wood $229 \mathrm{mg} \mathrm{m}^{-3}$ and pine wood $97 \mathrm{mg} \mathrm{m}^{-3}$. It is also possible to reduce $\mathrm{CO}$ and NOx emissions by adding calcium and magnesium compounds to poplar wood pellets- $\mathrm{Ca}, \mathrm{Mg}$-lignosulphonate. $\mathrm{SO}_{2}$ and $\mathrm{CH}_{4}$ emissions do not have such a clear tendency when additives from sewage sludge are used [38,43]. However, $\mathrm{SO}_{2}$ increases after adding $\mathrm{Ca}, \mathrm{Mg}$-lignosulphonate to wood pellets [13].

\section{Conclusions and Perspectives for Further Research}

- The selected materials from waste biomass can be effectively used to produce energy. In perspective, pellets from wood materials mixture M1 (WS + WD; 1:1) can be a good variant of solid fuel. The addition of sewage sludge hygienized with lime (mostly mineral material) can disturb the process of biomass combustion, which resulted in incomplete fuel combustion. Wood, straw and sewage sludge mixture M17 (WS + S + SS; 7:2:1) turned out to be the best energy material prepared with the sewage sludge addition. It should be taken into account not to add more than $5 \%$ of lime to the whole fuel mixture, including the use of lime-treated sewage sludge by means of co-combustion.

- As an effect of sewage sludge addition, an increased $\mathrm{pH}$ and relatively high $\mathrm{Ca}, \mathrm{Mg}, \mathrm{Na}$ and $\mathrm{Fe}$ were found. The high potassium content was related to the construction of the material, which was solely based on straw, or the presence of straw in the mixtures. These elements will remain in the ash after the combustion of the pellets. As a result, the material rich in elements, being the desired fertilizer components, is created. Some problems can be connected with a high $\mathrm{pH}$ of ash (i.e., in the case of coniferous and heather cultivation) and high $\mathrm{Ca}, \mathrm{Mg}$ and $\mathrm{Na}$ content relative to the other elements (ionic antagonism). 
- Some materials containing lime-treated sewage sludge could have a relatively higher content of $\mathrm{Cr}$. The evaluated situation shows the content of $\mathrm{Cr}$ lower than permitted by Polish law. However, the use of these materials for a long time as fertilizers may result in the accumulation of this undesirable metal in soil.

- A different problem is the durability of pellets prepared from various biomass mixtures. Wood shavings stabilized with sewage sludge hygienized with lime (mixtures M3, M13, M18, M19 and M22) are a good material for making durable pellets; from this point of view the proportion of sewage sludge in mixtures should be at least $20 \%$.

- Due to the possible difficulties with burning a solid fuel material with a high content of mineral components, it is recommended to use mixtures M18 (WS + WD + SS; 3:1:1) and M19 (WS + S + SS; 3:1:1) for this purpose.

- The addition of sewage sludge to the biomass of M2, i.e., the production of material M17, resulted in a reduction of $\mathrm{CO}$ emissions and the elimination of $\mathrm{H}_{2}$ emissions. At the same time, there was an increase in $\mathrm{NO}, \mathrm{NO}_{2}, \mathrm{NOx}, \mathrm{CO}_{2}$ and $\mathrm{H}_{2} \mathrm{~S}$ emissions. Further research is needed to optimize the combustion process parameters of individual biomass mixtures in terms of reducing the environmental impact of the occurring gaseous and residual products.

The combustion of waste biomass is difficult due to the highly varied composition of this fuel, both in terms of the combustion process and its environmental impact. The addition of a calcium-based mineral fraction to fuel, which is often described in the literature as effectively improving some parameters of boiler operation, is problematic, since it may cause some phenomena that are harmful to the environment. Studies should be continued to find an optimum composition of biomass mixtures to obtain a good calorific value with limited emissions of acidic anhydrides to the atmosphere. It would also be necessary to analyze how combustion technology (mainly the thermal characteristics of this process) affects the release of gases to the atmosphere in the case of fuels from pure biomass and biomass modified with lime. It should also be considered whether there is a significant difference in this respect between the addition of pure calcium carbonate and the addition of granulate from municipal sewage sludge hygienized with lime. It would also be necessary to check whether there would be any difference between the addition of municipal sewage sludge hygienized with lime in the form of granules and in the form of a non-granulated mixture.

Author Contributions: Conceptualization, A.G., M.M. and W.S.; Data curation, M.M. and W.S.; Formal analysis, A.G., M.M. and W.S.; Funding acquisition, A.G.; Investigation, A.G., M.M. and W.S.; Methodology, A.G., M.M. and W.S.; Project administration, A.G.; Supervision, A.G.; Validation, A.G. and M.M.; Visualization, M.M.; Writing—original draft, A.G., M.M. and W.S.; Writing—review \& editing, A.G. and M.M.

Funding: This study was carried out as a project of the European Regional Development Fund. The Lubusz 2020 Operational Programme. Activity 1.2 Developing Enterprise-A Voucher for Innovation No. 015/2/2017 and 024/2/2017.

Conflicts of Interest: The authors declare no conflict of interest.

\section{References}

1. Tchapda, A.H.; Pisupati, S.V. A Review of Thermal Co-Conversion of Coal and Biomass/Waste. Energies 2014, 7, 1098-1148. [CrossRef]

2. Bazan-Krzywoszańska, A.; Mrówczyńska, M.; Skiba, M.; Sztubecka, M. Sustainable urban development on the example of the housing development of Zielona Góra (Poland), as a response to the climate policy of the European Union. In Proceedings of the 10th International Conference on Environmental Engineering, Vilnius, Lithuania, 27-28 April 2017. [CrossRef]

3. Energy 2018. Statistical Analyses; Statistics Poland: Warsaw, Poland, 2018; p. 28.

4. Islas, J.; Manzini, F.; Masera, O.; Vargas, V. Solid Biomass to Heat and Power. In The Role of Bioenergy in the Emerging Bioeconomy: Resources, Technologies, Sustainability and Policy; Academic Press: Cambridge, MA, USA, 2019; pp. 145-177. 
5. Hamelin, L.; Borzęcka, M.; Kozak, M.; Pudełko, R. A spatial approach to bioeconomy: Quantifying the residual biomass potential in the EU-27. Renew. Sustain. Energy Rev. 2019, 100, 127-142. [CrossRef]

6. Antizar-Ladislao, B.; Turrion-Gomez, J.L. Decentralized Energy from Waste Systems. Energies 2010, 3, 194-205. [CrossRef]

7. Amaral, S.S.; de Carvalho, J.A., Jr.; Costa, M.A.M.; Pinheiro, C. Particulate Matter Emission Factors for Biomass Combustion. Atmosphere 2016, 7, 141. [CrossRef]

8. Mboumboue, E.; Njomo, D. Biomass resources assessment and bioenergy generation for a clean and sustainable development in Cameroon. Biomass Bioenergy 2018, 118, 16-23. [CrossRef]

9. Monteiro, E.; Mantha, V.; Rouboa, A. Portuguese pellets market: Analysis of the production and utilization constrains. Energy Policy 2012, 42, 129-135. [CrossRef]

10. Houshfar, E.; Løvås, T.; Skreiberg, Ø. Experimental Investigation on NOx Reduction by Primary Measures in Biomass Combustion: Straw, Peat, Sewage Sludge, Forest Residues and Wood Pellets. Energies 2012, 5, 270-290. [CrossRef]

11. Wzorek, M. Characterisation of the properties of alternative fuels containing sewage sludge. Fuel Process. Technol. 2012, 104, 80-89. [CrossRef]

12. Moya, R.; Tenorio, C.; Oporto, G. Short Rotation Wood Crops in Latin American: A Review on Status and Potential Uses as Biofuel. Energies 2019, 12, 705. [CrossRef]

13. Monedero, E.; Portero, H.; Lapuerta, M. Combustion of Poplar and Pine Pellet Blends in a $50 \mathrm{~kW}$ Domestic Boiler: Emissions and Combustion Efficiency. Energies 2018, 11, 1580. [CrossRef]

14. Toscano, G.; Alfano, V.; Scarfone, A.; Pari, L. Pelleting Vineyard Pruning at Low Cost with a Mobile Technology. Energies 2018, 11, 2477. [CrossRef]

15. Xu, J.; Chang, S.; Yuan, Z.; Jiang, Y.; Liu, S.; Li, W.; Ma, L. Regionalized Techno-Economic Assessment and Policy Analysis for Biomass Molded Fuel in China. Energies 2015, 8, 13846-13863. [CrossRef]

16. Cuellar, A.D.; Herzog, H. A Path Forward for Low Carbon Power from Biomass. Energies 2015, 8, $1701-1715$. [CrossRef]

17. Lopes, E.J.; Queiroz, N.; Yamamoto, C.I.; da Costa Neto, P.R. Evaluating the emissions from the gasification processing of municipal solid waste followed by combustion. Waste Manag. 2018, 73, 504-510. [CrossRef] [PubMed]

18. Chen, W.-S.; Chang, F.-C.; Shen, Y.-H.; Tsai, M.-S. The characteristics of organic sludge/sawdust derived fuel. Bioresour. Technol. 2011, 102, 5406-5410. [CrossRef] [PubMed]

19. Jiang, L.; Yuan, X.; Xiao, Z.; Liang, J.; Li, H.; Cao, L.; Wanga, H.; Chen, X.; Zeng, G. A comparative study of biomass pellet and biomass-sludge mixed pellet: Energy input and pellet properties. Energy Convers. Manag. 2016, 126, 509-515. [CrossRef]

20. Kacprzak, M.; Neczaj, E.; Fijałkowski, K.; Grobelak, A.; Grosser, A.; Worwag, M.; Rorat, M.; Brattebo, H.; Almås, Å.; Singh, B.R. Sewage sludge disposal strategies for sustainable development. Environ. Res. 2017, 156, 39-46. [CrossRef]

21. Pulka, J.; Manczarski, P.; Koziel, J.A.; Białowiec, A. Torrefaction of Sewage Sludge: Kinetics and Fuel Properties of Biochars. Energies 2019, 12, 565. [CrossRef]

22. Kijo-Kleczkowska, A.; Środa, K.; Kosowska-Golachowska, M.; Musiał, T.; Wolski, K. Combustion of pelleted sewage sludge with reference to coal and biomass. Fuel 2016, 170, 141-160. [CrossRef]

23. Kijo-Kleczkowska, A.; Środa, K.; Kosowska-Golachowska, M.; Musiał, T.; Wolski, K. Experimental research of sewage sludge with coal and biomass co-combustion, in pellet form. Waste Manag. 2016, 53, 165-181. [CrossRef]

24. Yilmaz, E.; Wzorek, M.; Akçay, S. Co-pelletization of sewage sludge and agricultural wastes. J. Environ. Manag. 2018, 216, 169-175. [CrossRef]

25. Jiang, J.; Du, X.; Yang, S. Analysis of the combustion of sewage sludge-derived fuel by a thermogravimetric method in China. Waste Manag. 2010, 30, 1407-1413. [CrossRef]

26. Obernberger, I. Physical characteristics and chemical composition of solid biomass fuels. In Script for the Lecture "Thermochemical Biomass Conversion"; Eindhofen University of Technology, Department for Mechanical Engineering, Section Process Technology: Eindhoven, The Netherlands, 2003; (Chapter 3).

27. Li, H.; Jiang, L.-B.; Li, C.-Z.; Liang, J.; Yuan, X.-Z.; Xiao, Z.-H.; Xiao, Z.-H.; Wang, H. Co-pelletization of sewage sludge and biomass: The energy input and properties of pellets. Fuel Process. Technol. 2015, 132, 55-61. [CrossRef] 
28. Kliopova, I.; Makarskiene, K. Improving material and energy recovery from the sewage sludge and biomass residues. Waste Manag. 2015, 36, 269-276. [CrossRef]

29. García-Maraver, A.; Popov, V.; Zamorano, M. A review of European standards for pellet quality. Renew. Energy 2011, 36, 3537-3540. [CrossRef]

30. Lehtikangas, P. Quality properties of pelletised sawdust, logging residues and bark. Biomass Bioenergy 2001, 20, 351-360. [CrossRef]

31. Sarenbo, S.L.; Claesson, T. Limestone and dolomite powder as binders for wood ash agglomeration. Bull. Eng. Geol. Environ. 2004, 63, 191-207. [CrossRef]

32. Shao, Y.; Wang, J.; Preto, F.; Zhu, J.; Xu, C. Ash Deposition in Biomass Combustion or Co-Firing for Power/Heat Generation. Energies 2012, 5, 5171-5189. [CrossRef]

33. Wang, Q.; Chen, J.; Han, K.; Wang, J.; Lu, C. Influence of $\mathrm{BaCO}_{3}$ on chlorine fixation, combustion characteristics and $\mathrm{KCl}$ conversion during biomass combustion. Fuel 2017, 208, 82-90. [CrossRef]

34. Statistical Yearbook—Lubuskie Voivodship 2017; Statistical Office: Zielona Gora, Poland, 2017.

35. Environment 2018. Statistical Analyses; Statistics Poland: Warsaw, Poland, 2018.

36. Szewrański, S.; Świąder, M.; Kazak, J.K.; Tokarczyk-Dorociak, K.; van Hoof, J. Socio-Environmental Vulnerability Mapping for Environmental and Flood Resilience Assessment: The Case of Ageing and Poverty in the City of Wrocław, Poland. Integr. Environ. Assess. Manag. 2018, 14, 592-597. [CrossRef]

37. Bindig, R.; Butt, S.; Hartmann, I.; Matthes, M.; Thiel, C. Application of Heterogeneous Catalysis in Small-Scale Biomass Combustion Systems. Catalysts 2012, 2, 223-243. [CrossRef]

38. Chen, G.-B.; Chatelier, S.; Lin, H.-T.; Wu, F.-H.; Lin, T.-H. A Study of Sewage Sludge Co-Combustion with Australian Black Coal and Shiitake Substrate. Energies 2018, 11, 3436. [CrossRef]

39. Zhang, D.; Huang, G.; Xu, Y.; Gong, Q. Waste-to-Energy in China: Key Challenges and Opportunities. Energies 2015, 8, 14182-14196. [CrossRef]

40. Polonini, L.F.; Petrocelli, D.; Parmigiani, S.P.; Lezzi, A.M. Influence on CO and PM Emissions of an Innovative Burner Pot for Pellet Stoves: An Experimental Study. Energies 2019, 12, 590. [CrossRef]

41. To, W.M.; Lee, P.K.C.; Ng, C.T. Factors Contributing to Haze Pollution: Evidence from Macao, China. Energies 2017, 10, 1352. [CrossRef]

42. Ngangyo-Heya, M.; Foroughbahchk-Pournavab, R.; Carrillo-Parra, A.; Rutiaga-Quiñones, J.G.; Zelinski, V.; Pintor-Ibarra, L.F. Calorific Value and Chemical Composition of Five Semi-Arid Mexican Tree Species. Forests 2016, 7, 58. [CrossRef]

43. Falemara, B.C.; Joshua, V.I.; Aina, O.O.; Nuhu, R.D. Performance Evaluation of the Physical and Combustion Properties of Briquettes Produced from Agro-Wastes and Wood Residues. Recycling 2018, 3, 37. [CrossRef] 